\title{
Intestinal healing in rats submitted to ethanol ingestion ${ }^{1}$
}

\author{
Cicatrização intestinal em ratos submetidos à ingestão de etanol
}

\author{
Rodrigo Severo de Camargo Pereira ${ }^{\mathrm{I}}$, Cláudia Nishida Hasimoto ${ }^{\mathrm{II}}$, Leonardo Pelafsky ${ }^{\mathrm{III}}$, Juan Carlos Llanos ${ }^{\mathrm{IV}}$, Daniele Cristina \\ Cataneov, César Tadeu Spadella $^{\mathrm{VI}}$, José Guilherme Minossi ${ }^{\mathrm{VII}}$
}

IPhD, Surgeon, Division of Gastroenterology Surgery, Surgery and Orthopedics Department, Botucatu School of Medicine, UNESP, Brazil. Involved with technical procedures, manuscript writing.

IIMaster, Surgeon, Division of Gastroenterology Surgery, Surgery and Orthopedics Department, Botucatu School of Medicine, UNESP, Brazil. Involved with technical procedures, animals care and biochemical analysis.

IIIMD, Surgeon, Division of Gastroenterology Surgery, Surgery and Orthopedics Department, Botucatu School of Medicine, UNESP, Brazil. Involved with technical procedures and animals care.

${ }^{\text {IV }} \mathrm{PhD}$, Associate Professor, Division of Gastroenterology Surgery, Surgery and Orthopedics Department, Botucatu School of Medicine, UNESP, Brazil. Critical review.

${ }^{v} \mathrm{PhD}$, Associate Professor, Division of Thoracic Surgery, Surgery and Orthopedics Department, Botucatu School of Medicine, UNESP, Brazil. Critical review and responsible for English language.

${ }^{\mathrm{V}} \mathrm{PhD}$, Chairman, Division of the Gastroenterology Surgery, Surgery and Orthopedics Department, Botucatu School of Medicine, UNESP, Brazil. Critical review.

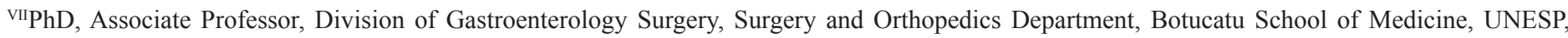
Brazil. Mentor, designed the protocol and critical review.

\section{ABSTRACT}

PURPOSE: To study the effect of alcoholism on intestinal healing and postoperative complications in rats.

METHODS: One hundred and sixty rats were divided into two groups: control and treated. The control group received water and the treated group 30\% ethanol. After 180 days, colotomy with anastomosis were performed. After, the groups were divided into four subgroups: 20 rats for study at the following moments: $4^{\text {th }}, 7^{\text {th }}, 14^{\text {th }}$ and $21^{\text {st }}$ postoperative. The analyzed parameters were: weight gain, breaking strength, tissue hydroxyproline, postoperative complications and histopathological study.

RESULTS: Weight gain was greater in the control group $(\mathrm{p}<0.05)$. When all the subgroups were clustered, breaking strength was significantly greater in the control $(\mathrm{p}<0.05)$. Histopathology and hydroxyproline dosage did not show differences. There were five surgical site infections in the treated group while the control group showed two $(p>0.05)$. Nine fistulas occurred in the treated group whereas the control group two $(\mathrm{p}<0.05)$. There were three deaths in the control group and seven in the treated group ( $\mathrm{p}>0.05$ ).

CONCLUSIONS: Treated group undergo a malnutrition process that is revealed by lower weight gain. Impaired intestinal healing as indicated by smaller breaking strength. There were a larger number of postoperative complications in the treated animals.

Key words: Wound Healing. Alcoholism. Ethanol. Tensile Strenght. Hydroxyproline. Rats.

\section{RESUMO}

OBJETIVO: Estudar o efeito do alcoolismo no processo de cicatrização intestinal e suas complicações pós-operatórias em ratos.

MÉTODOS: Cento e sessenta ratos foram divididos em dois grupos: tratado e controle. O controle recebeu água, enquanto o tratado etanol a 30\%. Após 180 dias foram realizadas colotomia, seguida de anastomose. Após os animais foram divididos em quatro subgrupos de 20 ratos para estudo nos seguintes momentos: $4^{\circ}, 7^{\circ}, 14^{\circ}$ e $21^{\circ}$ pós-operatório. Os parâmetros analisados foram: ganho de peso, força de ruptura, hidroxiprolina tecidual, complicações pós-operatórias e estudo histopatológico.

RESULTADOS: O ganho de peso foi superior no grupo controle $(\mathrm{p}<0,05)$. Após agrupamento dos momentos a força de ruptura foi superior no controle $(\mathrm{p}<0,05)$. Não houve diferença quanto à histopatologia e hidroxiprolina. Houve cinco infecções de incisão no grupo tratado, enquanto no controle ocorreram duas $(p>0,05)$. Houve nove fístulas no grupo tratado, enquanto no controle duas $(p<0,05)$. Ocorreram sete mortes no grupo tratado e apenas três no controle $(\mathrm{p}>0,05)$. 
CONCLUSÕES: No grupo tratado ocorreu um processo de subnutrição evidenciado pelo menor ganho de peso. Piora na cicatrização intestinal, indicada pela menor força de ruptura. Ocorreu um maior número de complicações pós-operatórias no grupo tratado.

Descritores: Cicatrização. Alcoolismo. Etanol. Resistência à Tração. Hidroxiprolina. Ratos.

\section{Introduction}

Abusive alcohol consumption is considered to be a serious public health problem, and it is responsible for $3.2 \%$ of mortality worldwide $^{1}$. In Brazil, an emerging country, the scenario is even worse. A Brazilian multicenter study on 107 cities with more than 200 thousand inhabitants showed prevalence of alcoholism in $11.2 \%$ of the studied population ${ }^{2}$.

Due to easy access, alcohol consumption in adolescence has progressively increased. Several studies report that 60 to $90 \%$ of students at the end of high school have already ingested some type of alcoholic beverage ${ }^{3-5}$, and the date of first ingestion between 14 and 15 years old ${ }^{6}$. This fact makes this issue even more serious, since it has been found that approximately $14 \%$ of the individuals who began consumption when they were younger than 14 years old became addicted, whereas only $2 \%$ of individuals whose first ingestion occurred when they were older than 19 years old became addicted ${ }^{7}$.

In the United States, of all car accidents associated with alcohol consumption, $4 \%$ resulted in death, and $42 \%$ in some lesion type, whereas in car crashes that were unrelated to the ingestion of alcoholic beverages, $0.6 \%$ resulted in death, and $31 \%$ in some type of injury ${ }^{8}$. Alcohol abuse is present in $53 \%$ of fatal traffic accidents victims ${ }^{9}$. In a General Hospital, $56 \%$ of the patients with head trauma by aggressions were drunk $^{10}$ and a recent research found frequent binge drinking to be the strongest predictor of both intoxicated rape and other forms of rape, with an odds ratio of 7.83 and 2.82 , respectively ${ }^{11}$.

Abusive and indiscriminate use of alcoholic beverages is responsible for more than 60 health aggravations, such as esophageal, stomach and liver cancer, cardiovascular diseases, hepatic cirrhosis, chronic pancreatitis and peptic ulcers in addition to traumas of all types ${ }^{12-14}$, with an estimate that the abuse of alcoholic beverages reduces the life expectancy in five years ${ }^{15}$. In many of such pathologies, interventions on the digestive tract may be required.

The gastrointestinal tract is the first body segment to come into contact with ethanol, and it is exposed to concentrations that are often larger than in other tissues ${ }^{16}$. The chronic ingestion of ethanol changes intestinal histology, resulting in reduced villi, increased microvascular permeability ${ }^{17}$ and cellular regeneration processes, with the possibility of carcinogenesis ${ }^{18}$.

Our research group has studied intestinal healing in clinical conditions considered to be deleterious to its development, such as malnutrition, peritoneal infection, use of non-hormonal anti-inflammatory agents and diabetes, which show healing delay with increased risk for dehiscence in the postoperative period ${ }^{19}$.

Despite the recent advancements in surgical techniques, intensive care and antibiotic therapy, anastomotic fistulas still concern surgeons and patients. In the world, a lot of thousands digestive-system surgeries occurred every year, with an estimate of 10 to $20 \%$ of anastomotic fistulas ${ }^{20,21}$.

Intestinal healing comprises a series of consecutive events that are carefully regulated in order to re-establish the immune barrier and heal the injured tissue. Failure or delay in one of such events may lead to anastomotic dehiscence.

The probable mechanisms involved in healing retardation would be related to reduced synthesis and/or increased collagenic lysis, in addition to delayed cellular regeneration. Collagen is responsible for all tissues resistance and by the strength and integrity of regeneration sites. Healing depends on the type and quantity of collagen fibers ${ }^{22}$.

As regards the abovementioned alcoholism problem, there is a series of alterations that may affect anastomosis in the intestinal tract, such as: malnutrition and hepatic lesions, in addition to the direct effect of ethanol on the mucosa in the digestive system, thus hindering its healing. For these reasons, the present study aims at analyzing the behavior of intestinal healing in rats submitted to ethanol ingestion.

\section{Methods}

The experimental protocol was conducted according to the Guide for the Care and Use of Laboratory Animals, published by the U.S. National Institute of Health. It was also approved by the Ethics and Animal Experimentation Committee of the Botucatu School of Medicine, Sao Paulo State University - UNESP. One hundred and sixty adult Wistar rats weighing approximately 180 to 200 grams were used. The animals were kept in polyurethane cages, each containing five rats. They were fed commercial chow and allowed to have free access to water. The diet was interrupted 12 hours prior to the surgical procedure. After a seven-day 
adaptation period in the Surgical Technique and Experimental Surgery, they were randomly distributed, according to the random number table ${ }^{23}$, into two groups as follows:

Control Group: consisted of 80 animals that were fed commercial chow and allowed to have free access to water for 180 days and then submitted to distal-colon anastomosis. This group was divided into four sub-groups of 20 rats each, and necropsy was performed 4, 7, 14 and 21 days after the surgical procedure.

Treated Group: consisted of 80 animals that received $30 \%$ ethanol and commercial chow for 180 days and then submitted to distal-colon anastomosis. This group was divided into four subgroups of 20 rats each, and necropsy was performed 4, 7, 14 and 21 days after the surgical procedure.

Twenty animals from each group, five from each subgroup were allocated for histopathological study while the remaining 60 were allocated for study of the following variables: breaking strength, hydroxyproline, postoperative complications and weight. These parameters were analyzed in 15 animals at each moment. The animals that died before the surgery were replaced. Ethanol dilution was performed by using Gay-Lussac alcoholmeter.

The animals were weighed on a Mark 8000 scale with capacity for 8,000 grams when admitted at the animal colony and immediately prior to the surgical procedure.

After the preconized period, the animals were anesthetized with sodium pentobarbital, 30 miligrams/kilogram, intraperitoneally. After anesthesia, the animals were weighed, which was followed by abdominal trichotomy, disinfection with $2 \%$ iodinated alcohol and a 5 centimeters median incision in the lower abdominal area. Next, total colotomy was performed five centimeters above the peritoneal deflection (Figure 1A). Then, end to end, colon-colonic anastomosis was carried out on a single plane, using separate total stitches with 6-0 polypropylene suture (Figure 1B). Wall closure was performed by the synthesis of the peritoneum, musculature and aponeurosis, with a single suture and separate stitches using 4-0 Nylon. The skin was sutured by using 4-0 Nylon suture and separate stitches. After the procedure, the rats were randomly selected for the moments according to the random number table ${ }^{23}$.

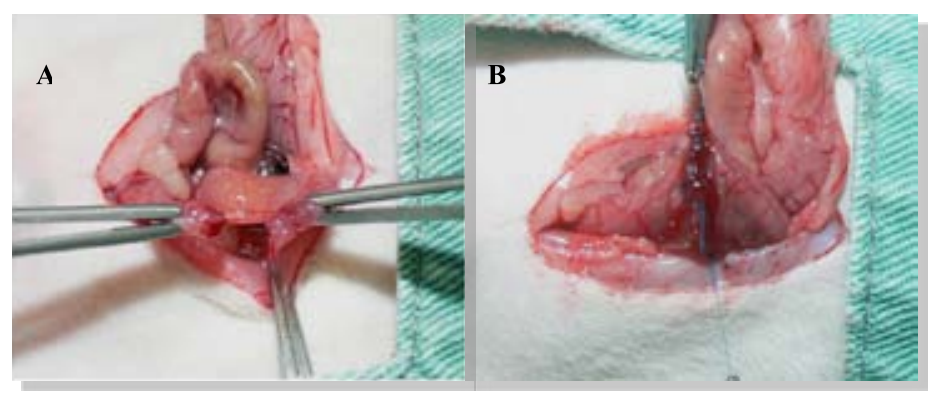

FIGURE 1 - A- Colotomy. B- Suture.
After the standardized period, 15 rats from each moment were again anesthetized and submitted to a new laparotomy for removal of a 3 centimeters colonic segment containing the anastomosis. The fragments were soaked in a mixture of saline solution and papaverine hydrochloride (250 miligram/liters) for 30 minutes at $37^{\circ} \mathrm{C}$. The segments were then submitted to breaking strength evaluation. The rats were then sacrificed by using an intramuscular anesthetic overdose of sodium pentobarbital.

In order to evaluate longitudinal breaking strength, the Mechanic Assay Universal Testing Machine EMIC DL10-000 was used.

Morphological analysis was performed in the Department of Pathology of the Botucatu School of Medicine, Sao Paulo State University - UNESP. After the standardized period, five rats remaining from each moment were again anesthetized for removal of a 3 centimeters colonic segment with the anastomosis in its center. Three cuts were performed perpendicularly to the anastomosis region, and slides were prepared and respectively stained with Hematoxylin-eosin and Masson's Trichrome. The criteria adopted for the histopathological evaluation of the healing process were: mucosal regeneration, inflammatory reaction, granulation tissue and collagenogenesis.

The biochemical analyses were performed at the Internal Medicine Experimental Laboratory of the Botucatu School of Medicine, UNESP. After application of breaking strength, the tissues were cut, and the segments consisting of both anastomotic borders were removed. Tissue hydroxyproline was dosed according to the method described by Switzer ${ }^{24}$. The variables used to evaluate surgical complication were: deaths, anastomotic dehiscence and surgical site infection.

For statistical analysis, Tukey's method was used for variables breaking strength and tissue hydroxyproline dosage. In each group and at each moment, 15 animals were used, and the means and standard deviations were calculated as indicators for central tendency and variability, respectively. The level of significance used was of 5\%. Surgical complications, deaths, infections and fistulas were analyzed by the $\mathrm{Z}$ test. The level of significance used was of $5 \%$. The rats' weight gain was analyzed by the chi-square test. The level of significance used was of $5 \%$.

\section{Results}

Weight gain in the group submitted to ethanol ingestion until the date of surgery varied from 108.0 to 321.0 grams, with a mean and standard deviation of $218.7 \pm 49.4$ grams whereas, in the control group, it ranged from 211.0 to 513.0 grams, with a 
mean and standard deviation of $303.5 \pm 57.6$ grams. Significant difference was found between the groups $(p<0.05)$. The mean and standard deviation of the animals' weight on the day of surgery in each group and at each moment as well as the general mean of each group and the statistical interpretation are shown in Table 1.

TABLE 1 - Weight' animals per group and moments.

\begin{tabular}{cccccc}
\hline \multirow{2}{*}{ Group } & \multicolumn{5}{c}{ Moments } \\
\cline { 2 - 6 } & $\mathrm{M} 1(\mathrm{~g})$ & $\mathrm{M} 2(\mathrm{~g})$ & $\mathrm{M} 3(\mathrm{~g})$ & $\mathrm{M} 4(\mathrm{~g})$ & $\mathrm{A} 11(\mathrm{~g})$ \\
\hline $\begin{array}{c}\text { Treated } \\
\text { Group }\end{array}$ & $\begin{array}{c}428.2 \pm 50.2 \\
\text { (B) }\end{array}$ & $\begin{array}{c}439.0 \pm 53.1 \\
(\mathrm{~B})\end{array}$ & $\begin{array}{c}403.8 \pm 49.7 \\
(\mathrm{~B})\end{array}$ & $\begin{array}{c}393.6 \pm 45.0 \\
(\mathrm{~B})\end{array}$ & $\begin{array}{c}409.1 \pm 48.4 \\
(\mathrm{~B})\end{array}$ \\
$\begin{array}{c}\text { Control } \\
\text { Group }\end{array}$ & $\begin{array}{c}547.7 \pm 65.5 \\
\text { (A) }\end{array}$ & $\begin{array}{c}467.2 \pm 44.2 \\
(\mathrm{~A})\end{array}$ & $\begin{array}{c}484.2 \pm 44.1 \\
(\mathrm{~A})\end{array}$ & $\begin{array}{c}475.4 \pm 39.6 \\
(\mathrm{~A})\end{array}$ & $\begin{array}{c}493.6 \pm 57.8 \\
(\mathrm{~A})\end{array}$ \\
Interpretation & $\mathrm{A}>\mathrm{B}$ & $\mathrm{A}>\mathrm{B}$ & $\mathrm{A}>\mathrm{B}$ & $\mathrm{A}>\mathrm{B}$ & $\mathrm{A}>\mathrm{B}$ \\
\hline
\end{tabular}

The means and standard deviations for the breaking strengths were respectively of $225.1 \pm 76.8$ gramsforce on the $4^{\text {th }}$ postoperative day; $282.3 \pm 76.2$ gramsforce on the $7^{\text {th }}$ day; $476.5 \pm 94.8$ gramsforce on the $14^{\text {th }}$ day and $535.2 \pm 133.3$ gramsforce no $21^{\text {st }}$ day in the treated group. In the control group, such values were $257.0 \pm 46.7$ gramsforce on the $4^{\text {th }}$ postoperative day; $340.9 \pm 64.7$ gramsforce on the $7^{\text {th }}$ day; $535.2 \pm 113.2$ gramsforce on the $14^{\text {th }}$ day and $602.6 \pm 96.2$ gramsforce on the $21^{\text {st }}$ day. Although the breaking strength means were higher in control group, there were no statistically significant differences between the groups at each moment, this is shown by a significant interaction group * moment was not significant $(\mathrm{P}>0.05)$. There was a difference between the overall mean of the control group in contrast to the treated group ( $\mathrm{TG}<\mathrm{GC}$ ) and also showed differences between the overall averages of the moments, being $\mathrm{M} 1=\mathrm{M} 2<\mathrm{M} 3=\mathrm{M} 4$ (Figure 2).

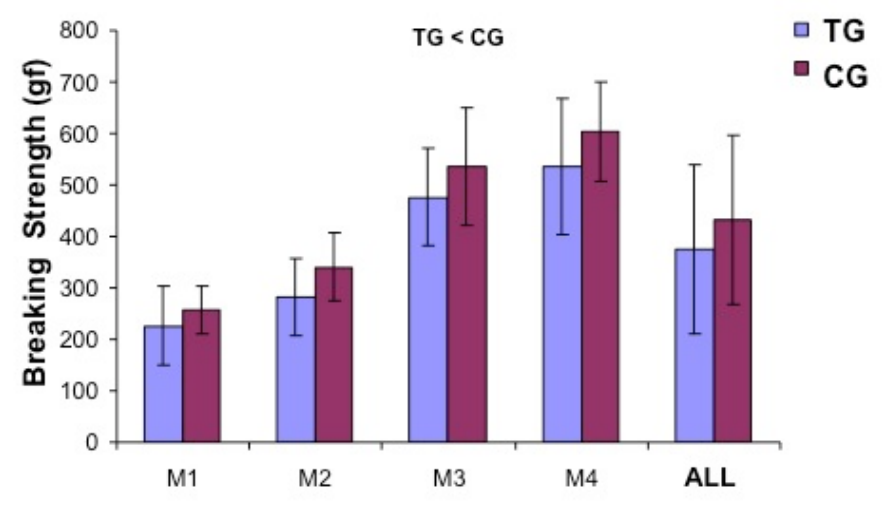

FIGURE 2- Means and standard deviation for the breaking strengths at each moment $(p>0.05)$ and general mean in each group in grams force $(\mathrm{p}=0.03)$.
In the treated group, the mean/standard deviation for the tissue hydroxyproline dosage was $4.98 \pm 2.20 \mathrm{micrograms} /$ deciliter on the $4^{\text {th }}$ postoperative day; $7.82 \pm 1.50 \mathrm{micrograms} /$ deciliter on the $7^{\text {th }}$ postoperative day; $11.02 \pm 3.00$ micrograms/deciliter on the $14^{\text {th }}$ postoperative day and $16.64 \pm 6.90 \mathrm{micrograms} /$ deciliter on the $21^{\text {st }}$ postoperative day. In the control group, the values were respectively $6.31 \pm 2.10 \mu \mathrm{g} / \mathrm{ml}$ on the $4^{\text {th }}$ postoperative day; $9.08 \pm 1.50 \mu \mathrm{g} / \mathrm{ml}$ on the $7^{\text {th }}$ postoperative day; $12.11 \pm 1.30$ micrograms/deciliter on the $14^{\text {th }}$ postoperative day and $14.33 \pm 2.60 \mathrm{micrograms} /$ deciliter on the $21^{\text {st }}$ postoperative day. The hydroxyproline dosage did not show differences between the groups at each studied moment, but a significant difference was only found between the moments, with the smallest value at moment $\mathrm{M}_{1}$ and the largest at moment $\mathrm{M}_{4}$ (Figure 3).

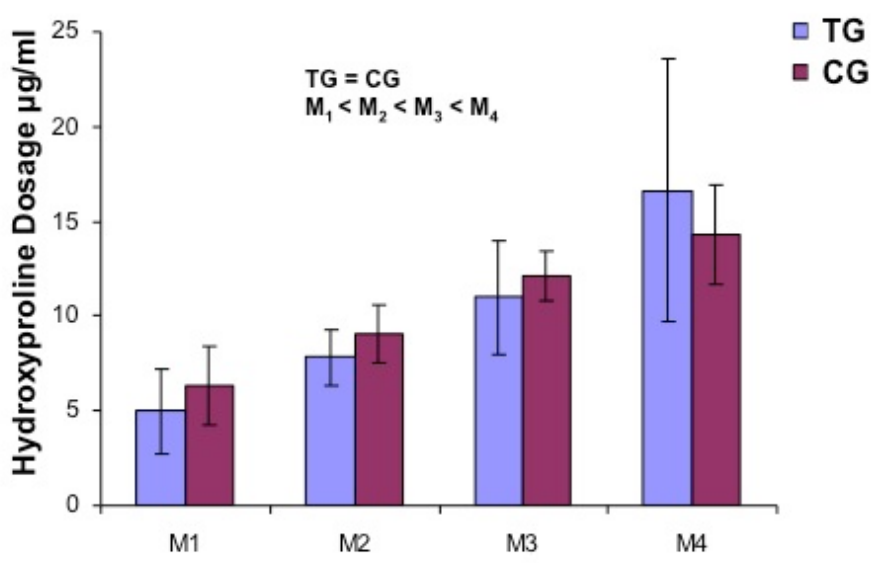

FIGURE 3 - Hydroxyproline dosage: mean and standard deviation at each moment.

The histopathological analysis did not show significant alterations between the control group and the treated group. No delay was observed for the intestinal healing phases in the group submitted to ethanol ingestion as compared to the animals in the control group. On the first postoperative days, partial mucosal regeneration occurred with development to complete healing in four of the five samples on the $21^{\text {st }}$ day in both groups. At first, inflammatory reaction was incipient on the $4^{\text {th }}$ day after the procedure, with slight neutrophilic exudate, a process that showed a major increase on the $7^{\text {th }}$ day after the procedure. On the $21^{\text {st }}$ day, there was virtually no inflammatory process in both groups. As regards the formation of granulation tissue and collagenogenesis, the presence of a few neoformed vessels was observed on the $4^{\text {th }}$ day. They were perpendicular to the anastomosis and showed a small number of fibroblasts and collagen fibers. Increased vascular formation occurred over time, with a larger number of fibroblasts and collagen. Collagen density increased progressively during 
the experiment. On the $21^{\text {st }}$ postoperative day, more structurally organized fibers were observed.

As regards complications, five surgery site infections occurred in the group submitted to ethanol ingestion whereas there was only one in the control group. The control group showed two anastomotic fistulas, and the treated group showed nine. Seven deaths occurred in the group submitted to ethanol ingestion whereas only three took place in the control group (Table 2).

TABLE 2 - Distribution of complication frequencies according to groups and statistics.

\begin{tabular}{ccccc}
\hline Group & Infection & Fistula & Deaths & $\begin{array}{c}\text { Total of } \\
\text { Complications }\end{array}$ \\
\hline $\begin{array}{c}\text { Treated } \\
\text { Group }\end{array}$ & $5(8.3 \%)$ & $9(15.0 \%)$ & $7(11.7 \%)$ & $21(35 \%)$ \\
Control & $1(1.7 \%)$ & $2(3.3 \%)$ & $3(5.0 \%)$ & $6(10.0 \%)$ \\
Group & & 0.02 & 0.18 & 0.001 \\
$p$ & 0.09 & & & \\
\hline
\end{tabular}

\section{Discussion}

Intestinal healing can be evaluated by means of the anastomosis breaking strength or collagen quantification ${ }^{22}$. Mechanically, the tissue repair process can be measured by both the longitudinal breaking strength used in our study and the radial bursting strength ${ }^{25}$. Longitudinal breaking strength is the measure of the intestinal wall resistance to forces applied on its longitudinal direction ${ }^{26}$ while radial breaking strength, also known as bursting pressure, measures the resistance of the intestinal wall to increased intraluminal pressure ${ }^{27}$. Longitudinal strength is determined by the quality and quantity of collagen fibers and, on the first three days, reflects primarily the resistance of suture materials ${ }^{28}$. On the first two days of healing, the breaking strength of suture, in either of the abovementioned methods, is low due to the action of collagenase ${ }^{25}$ which degrades part of the collagen existing in the lesioned tissue. Therefore, during this period, anastomosis resistance depends on the suture material and/or on the metal clamps used. As days go by, tissue resistance progressively increases, and it is proportional to collagen production by the tissue. Decrease in rupture strength, both longitudinal and radial during the first days after suturing is not consensual in the literature. A study that experimentally evaluated anastomoses in rats did not find any reduction in radial breaking strength on the first days of the healing process, but rather a progressive increase in such strength which was directly proportional to the increase in the number of neutrophils in the repair site ${ }^{26}$. The criticism in the literature as regards the sensitivity of the longitudinal breaking strength on the first three postoperative days is that it does not change in that period, thus remaining constant and progressively increasing from the $4^{\text {th }}$ day ${ }^{26,27}$. Such event has not been fully understood, and it probably occurs due to the fact that this measure is extremely sensitive to the surgical technique used in producing anastomoses ${ }^{26}$. In our study, a difference was soon found in breaking strength between the groups on the $4^{\text {th }}$ postoperative day, although without statistical significance. The use of the longitudinal breaking strength is criticized due to the difficulty to apply the same strength on the whole colonic circumference ${ }^{29}$. Radial breaking pressure is also questioned because of the difficulty to compare the various studies due to the absence of standardization with which the anastomosis is insufflated ${ }^{30}$ and if such measure must be taken in situ or with the piece out of the cavity ${ }^{31}$.

A recent meta-analysis has found that the pre-operative intestinal preparation is not related to colonic healing and that it may even increase the risk for fistula occurrence in the postoperative period $^{32}$. In our study, we chose to not perform colon preparation, and the animals were operated on by only two researchers so as to minimize the bias of surgical technique used.

Alcoholism is one of the major causes of malnutrition in the United States ${ }^{33}$. A study published in 1998 analyzed 32 alcoholic individuals without signs of hepatic dysfunction or intestinal malabsorption. Lower weight was observed in those patients, especially at the expense of body fat reduction ${ }^{34}$. Such weight reduction probably occurs due to the fact that the alcoholic individual can replace up to $50 \%$ of his daily intake of calories by alcohol ${ }^{35}$. Our experimental study showed substantially lower weight gain in the group submitted to ethanol ingestion, with statistical significance, thus revealing a correlation with the abovementioned studies.

Intestinal healing can be negatively influenced by several factors such as: surgical technique, suture materials used, malnutrition, anemia, diabetes, irradiation, shock, immunosuppression, infection and pre-operative blood transfusion. As regards the alcohol problem, a retrospective study analyzed 355 patients submitted to colonic and rectal anastomoses for benign and malignant diseases, and it found increased risk for dehiscence in individuals that ingested more than 35 doses of alcoholic beverages a week, considering that a dose contained from 9 to 13 grams of alcohol ${ }^{36}$. A Danish article published in 2005, including 5.181 patients submitted to coloproctologic surgeries due to neoplasias, confirmed the abovementioned 
information as it found significant worsening in intestinal healing and an increased rate of anastomotic fistulas ${ }^{37}$. These data are in agreement with those in our study, which found smaller breaking strength in the anastomoses of individuals to ethanol intake, in addition to a larger number of fistulas, both with statistical significance. The longitudinal breaking strength of anastomoses at the four postoperative moments was larger in the control group, although without statistical significance, which may be due to the small number of animals evaluated at those moments. However, when analyzed by groups, control group showed significantly larger breaking force than treated group. Other studies have also confirmed the negative influence of alcohol abuse, both acute and chronic, on the tissue healing process ${ }^{38-42}$. There is evidence that not only chronic alcohol abuse delays healing, but its acute ingestion previously to the surgical event also does. An experimental study analyzed the cutaneous healing of rats submitted to moderate doses of ethanol (100 miligrams/deciliter) and concluded that drastic worsening in the proliferative phase of the tissue healing process and decreased collagen synthesis occurred ${ }^{41}$.

The biochemical measurements of intestinal healing mainly comprise tissue hydroxyproline and the collagen deposition rate ${ }^{25}$. In our study, it was observed that the amount of hydroxyproline significantly increased over time at all studied moments, but no difference was found for its dosage between the groups, which may be due to the fact that chronic alcohol abuse does not affect the amount of collagen production or change only the quality of collagen produced. Another possibility would be the increase of enzyme collagenase on the anastomotic site, an event that would cause greater collagen degradation, which is not quantified by hydroxyproline dosage, since this method only measures collagen production, but not its degradation. The effect of ethanol probably begins in the inflammatory phase of cicatrization and also influences the later phases of process and tissue repair An experimental study evaluated cutaneous healing among rats and showed that the production of chemoattractive cytokines by neutrophils had decreased in the group submitted to ethanol ingestion, which had been caused by the decrease in interleucin- $1 \beta$ production in the lesioned tissue ${ }^{43}$. Deficiency of such interleukin reduces topical inflammation and the expression of adherence molecules in endothelial cells, in addition to hindering cellular infiltration to the target tissue $e^{43-45}$.

In our study, no significant alterations were found between the groups as concerns the histopathological analysis. The absence of difference occurred due to the fact that light microscopy is a "rough" method to study ethanol-mediated alterations in the tissue repair process since such alterations probably occur in the ultra- structural level of collagen and in the biochemistry of intestinal healing. Additionally, hematoxylin-eosin and Masson's trichrome staining, which was used in our study, is not a quantitative method for collagen dosage, and it was utilized only to illustrate the healing process of colonic anastomoses.

A published article which compiling studies conducted from 1967 to 1998 analyzed pre-operative alcoholism and its postoperative morbidity ${ }^{46}$. The most common complications found by the authors were bleeding, infections and cardiopulmonary insufficiency that required intensive care therapy ${ }^{46}$. A study published in 2007 analyzed 163.624 patients submitted to surgical procedures and detected 14 independent variables for surgical site infection risk, and one of them was alcoholism ${ }^{47}$. Our study agrees with previous investigations, as it found a total number of complications in treated group with statistical significance and fivefold more surgery-site infections in the treated group for which no statistical difference was found probably due to the small number of animals.

It is known that ethanol modulates immune response in a complex fashion ${ }^{48}$, including the increase in the blood levels of certain immunoglobulins ${ }^{49}$. Despite such increase, alcoholic patients are knowingly immunodeficient, which probably results from a deregulation in antibody production due to cytokine alterations ${ }^{49}$, suppression of processes involving lymphocyte migration ${ }^{50}$ and reduction in phagocytosis capacity of monocytes, neutrophils and macrophages ${ }^{51}$. An article published after a symposium held in the United States which compiled studies on cytokines and alcohol suggests that the acute and moderate intake of ethanol leads to a dual anti-inflammatory effect due to pro-inflammatory inhibition, in addition to an increase in the anti-inflammatory cytokines produced by monocytes ${ }^{46}$. Despite all these alcohol-dependent immunological alterations, other factors such as malnutrition and smoking are likely to contribute to an alcoholic individual's susceptibility to infections ${ }^{46}$. An article published in 2004 found decreased levels of cytokines interleucin $-1 \beta$, interleucin -6 and interleucin -8 at the beginning of infection in alcoholic patients, thus corroborating the other findings for immunosuppression in this group ${ }^{52}$. A study published in 2002 analyzed 45 patients, 25 of whom were alcoholics, submitted to resections of tumors in the high digestive tract and who required an intensive care regimen in the postoperative period ${ }^{53}$. A higher infection rate was found for alcoholics, $68 \%$ as compared to $30 \%$, in addition to a longer period of mechanical ventilation and the need for an intensive care regimen ${ }^{53}$. A Danish study has also found a significant increase in postoperative mortality in alcoholic patients submitted to curative resection for lung cancer ${ }^{30}$. Postoperative mortality was threefold 
higher in alcoholic patients in a study conducted by Tonnesen and Kehlet $^{46}$. Our experimental study found 2.33 fold more deaths in rats submitted to ethanol intake, a fact that is in agreement with the previously mentioned studies.

The mechanism related to this larger number of complications is multifactor, including the dysfunction of multiple organs and systems, an exaggerated response to surgical stress and the abstinence syndrome ${ }^{46}$, probably associated with the lack of various nutrients. Additionally, the response to surgical stress contributes to reduced immunity, coagulation deficit and cardiac overload, which together can increase the rates of surgical complications $^{46}$. It is important to point out a randomized and controlled trial that analyzed 42 alcoholic patients without hepatic diseases who, after one month of abstinence, showed significantly reduced morbidity following the surgical procedure ${ }^{54}$.

\section{Conclusions}

The animals submitted to ethanol intake presented a malnutrition process shown by significantly lower weight gain in relation to the control group. They showed impaired intestinal healing as demonstrated by the significantly smaller longitudinal breaking strength in the treated group. They also displayed a higher rate of postoperative complications characterized by a larger number of lesion infections, fistulas and higher mortality.

\section{References}

1. Meloni JN, Laranjeira R. Custo social do consumo de álcool. Rev Psiquiatr. 2004;26S 1:7-10.

2. Carlini EA, Galduróz JCF, Noto AR. Levantamento domiciliar sobre o uso de drogas no Brasil - 2001. São Paulo: Centro Brasileiro de Informação sobre Drogas Psicotrópicas, Departamento de Psicobiologia da Escola Paulista de Medicina e SENAD -Secretaria Nacional Antidrogas, Presidência da República, Gabinete de Segurança Nacional; 2002. p.480.

3. Carlini-Cotrim B, Gazal-Carvalho C, Gouveia N. Health behavior among students of public and private schools in the metropolitan area of Sao Paulo, Brazil. Rev Saúde Pública. 2000;34:636-45.

4. Galduroz JC, Noto AR, Fonseca AM. Levantamento sobre o consumo de drogas psicotrópicas entre estudantes do ensino médio e fundamental da rede pública de ensino nas 27 capitais brasileiras-2004. São Paulo: CEBRID.

5. Schmid H, Ter Bogt T, Godeau E, Hublet A, Dias SF, Fotiou A. Drunkenness among young people: across national comparisson. J Stud Alcohol. 2003;64:650-61.

6. Coleman L, Cater S. Fourteen- to 17-year-olds' experience of risky drinking - a cross-sectional survey undertaken in south-east England. Drug Alcohol Rev. 2004;23:351-3.

7. DeWit DJ, Adlaf EM, Offord DR, Ogborne AC. Age at first alcohol use: a risk factor for the development of alcohol disorders. Am J Psychiatry. 2000;157:745-50.

8. Hingson R, Winter M. Epidemiology and consequences of drinking and driving. Alcohol Res Health. 2003;27:63-78.
9. Abreu AMM, Lima JMB, Matos LN, Pillon SC. Uso de álcool em vítimas de acidentes de trânsito: estudo do nível de alcoolemia. Rev Latino-Am Enfermagem. 2010;18(S):513-20.

10. Carvalho TBO, Cancian LRL, Marques CG, Piatto VB; Maniglia JV; Molina FD. Six years of facial trauma care: an epidemiological analysis of 355 cases. Braz J Otorhinolaryngol. 2010;76(5):565-74.

11. Mohler-Kuo M, Dowdall GW, Koss MP, Wechsler H. Correlates of rape while intoxicated in a national sample of college women. J Stud Alcohol. 2004;65:37-45.

12. Gutjahr E, Gmel G, Rehm J. Relation between average alcohol consumption and disease. An overview. Eur Addict Res. 2001;7:11727.

13. Ridolfo B, Stevenson C. The quantification of drug-caused mortality and morbidity in Australia 1998. Canberra: Australian Institute of Health and Wealfare; 2001.

14. Single E, Robson L, Rehm J, Xie X. Morbidity and mortality attributable to alcohol tobacco and illicit drug use in Canada. Am J Public Health. 1999;89:385-90.

15. Mathers CD, Vos ET, Stevenson CE, Begg SJ. The burden disease and injury in Australia. Bull World Health Organ. 2001;79:1076-84.

16. Bronchal S, Nain CK, Prasad KK, Nada R, Sharma AK, Sinha SK, Singh K. Functional and morphological alterations in small intestine mucosa of chronic alcoholics. J Gastroenterol Hepatol. 2008;23(7 Pt 2): $43-8$.

17. Estrada G, Del Rio JA, Garcia J. Ethanol in vitro induces epithelial cell damage and altered kinetics in the developing rat intestine. Teratology. 1996;54:245-54.

18. Pronko P, Bardina L, Satonovskya V, Kuzmich A, Zimatkin S. Effect of chronic alcohol consumption in the ethanol and acetaldehyde metabolizing systems in the rat gastrointestinal tract. Alcohol Alcohol. 2002;37:229-35.

19. Ortolan EVP, Spadella CT, Caramori C, Machado JL, Gregorio EA, Rabello K. Microscopic, morphometric and ultrastructural analysia of anastomotic healing in the intestine of normal and diabetic rats. Exp Clin Endocrinol Diabetes. 2008;116:198-202.

20. Robson MC, Steed DL, Franz MG. Wound healing: biologic features and approaches to maximize healing trajectories. Curr Probl Surg. 2001;38:71-140.

21. Vignali A, Fazio VW, Lavery IC, Milsom JW, Church JM, Hull TL, Strong SA, Oakley JR. Factors associated with the occurrence of leaks in stapled rectal anastomoses: a review of 1014 patients. J Am Coll Surg. 1997;77:113-21.

22. Perez AC, Matos D, Montero EFS, de Souza HS, Barbosa FC, Saad F, Dip N. Effects of Sodium Hyaluronate and Carboxymethylcellulose membrane on collagen and fibroblast formation in bowel suture healing: experimental study in rats. Acta Cir Bras. 2005;20:15-21.

23. Dixon WJ, Massey Junior FJ. Introduction to statistical analysis. 3ed. New York: McGrawhill; 1969.

24. Switzer BR. Determination of hydroxyproline in tissue. J Nutr Biochem. 1991;2:229-231.

25. Thompson SK, Chang EY, Jobe BA. Clinical review: healing in gastrointestinal anastomoses, Microsurgery. 2006;26:131-6.

26. Mansson P, Zhang XW, Jeppsson B, Thorlacius H. Anastomotic healing in the rat colon: comparison between a radiological method, breaking strength and bursting pressure. Int $\mathrm{J}$ Colorectal Dis. 2002; 17:420-5.

27. Weiber S, Jiborn H, Zederfeldt B. Preoperative irradiation and colonic healing. Eur J Surg. 1994;160:47-51.

28. Cahill RA, Sheehan KM, Scanlon RW, Murray FE, Kay EW, Redmond HP. Effects of a selective cyclo-oxygenase 2 inhibitor on colonic anastomotic and skin wound integrity. $\mathrm{Br} \mathrm{J}$ Surg. 2004;91:1613-8.

29. Nelsen TS, Anders CJ. Dynamic aspects of small intestine rupture 
with special consideration of anastomotic strength. Arch Surg. 1966;93:309-14

30. Neuenschwander AU, Pedersen JH, Krasnik M, Tonnesen H. Impaired postoperative outcome in chronic alcohol abusers after curative resection for lung cancer. Eur J Cardiothorac Surg. 2002;22:287-91.

31. Hendriks T, Mastboom WJ. Healing of experimental intestinal anastomoses. Parameters for repair. Dis Colon Rectum. 1990;33:891901.

32. Slim K, Vicaut E, Panis Y, Chipponi J. Meta-analysis of randomized clinical trials of colorectal surgery with or without mechanical bowel preparation. Br J Surg. 2004;91:1125-30.

33. Markowitz JS, McRae AL, Sonne SC. Oral nutritional supplementation for the alcoholic patient: a brief overview. Ann Clin Psychiatry. 2000;12:153-8.

34. Addolorato G, Capristo E, Greco AV, Stefanini GF, Gasbarrini G. Influence of chronic alcohol abuse on body weight and energy metabolism: is excess ethanol consumption a risk factor for obesity or malnutrition? J Intern Med. 1998;244:387-95.

35. Lieber CS. The influence of alcohol on nutritional status. Nutr Rev. 1998;46:241-54

36. Sorensen L, Jorgensen T, Kirkeby LT, Skovdal J, Vennits B, WilleJorgensen P. Smoking and alcohol abuse are major risk factors for anastomotic leakage in colorectal surgery. Br J Surg. 1999;86:92731.

37. Nickelsen TN, Jorgensen T, Kronborg O. Lifestyle and 30day complications to surgery for colorectal cancer. Acta Oncol. 2005;44:218-23.

38. Gaston MS, Simpson AHRW. Inhibition of fracture healing. J Bone Joint Surg Br. 2007;89:1553-60.

39. Koo S, Konig Junior B, Mizusaki CI, Allegrini S Jr, Yoshimoto M, Carbonari MJ. Effects of alcohol consumption on osseointegration of titanium implants in rabbits. Implant Dent. 2004;13:232-7.

40. Nyquist F, Overgaard A, Duppe H, Obrant KJ. Alcohol abuse and healing complications after cervical hip fractures. Alcohol Alcohol. 1998;33:373-80

41. Radek KA, Matthies AM, Burns AL, Heinrich SA, Kovacs EJ, Dipietro LA. Acute ethanol exposure impairs angiogenesis and proliferative phase of wound healing. Am J Physiol Heart Circ Physiol. 2005;289:1084-90.

42. Slomiany BL, Piotrowski J, Slomiany A. Suppression of endothelinconverting enzyme-1during buccal mucosal ulcer healing: effect of chronic alcohol ingestion. Biochem Biophys Res Commun. 2000;271:318-22

43. Fitzgerald DJ, Radek KA, Chaar M, Faunce DE, DiPietro LA, Kovacs EJ. Effects of acute ethanol exposure on the early inflammatory response after excisional injury. Alcohol Clin Exp Res. 2007;31:317-23.

44. Brito BE, O'Rourke LM, Pan Y, Anglin J, Planck SR, Rosenbaum JT. IL-1 and TNF receptor-deficient mice show decreased inflammation in an immune complex model of uveitis. Invest Ophthalmol Vis Sci. 1999;40:2583-9.

45. Labow M, Shuster D, Zetterstrom M, Nunes P, Terry R, Cullinan EB, Bartfai T, Solorzano C. Moldawer LL, Chizzonite R, McIntyre $\mathrm{KW}$. Absence of IL-1 signaling and reduced inflammatory response in IL-1 type 1 receptor-deficient mice. J Immunol. 1997;159:245261.

46. Tonnesen $\mathrm{H}$, Kehlet H. Preoperative alcoholism and postoperative morbidity. Br J Surg. 1999;86:869-74

47. Neumayer L, Hosokawa P, Itani K, El-Tamer M, Henderson WG, Khuri SF. Multivariable predictors of postoperative surgical site infection after general and vascular surgery: results from the patient safety in surgery study. J Am Coll Surg. 2007;204:1178-87.
48. Cook RT, Waldschmidt TJ, Cook BL. Loss of CD5+and CD45RAhi B cell subsets in alcoholics. Clin Exp Immunol. 1996;103:304-10.

49. Crews FT, Bechara R, Brown LA, Guidot DM, Mandrekar P, Oak S, Qin L, Szabo G, Wheeler M, Zou J. Cytokines and alcohol. Alcohol Clin Exp Res. 2006;30:720-30

50. Chiappelli F, Kung M, Lee P, Pham L, Manfrini E, Villanueva P. Alcohol modulation of human normal T-cell activation, maturation and migration. Alcohol Clin Exp Res. 1995;19:539-44.

51. Watson RR, Borgs P, Witte M, McCuskey RS. Lantz C. Johnson MI. Mufti SI. Earnest DL. Alcohol immunomodulation and disease. Alcohol Alcohol. 1994;29:131-9.

52. Von Dossow V, Schilling C, Beller S, Hein OV, von Heymann C, Kox WJ, Spies CD. Altered immune parameters in chronic alcoholic patients at the onset of infection and of septic shock. Crit Care. 2004:8:312-21.

53. Sander M, Irwin M, Sinha P, Naumann E, Kox WJ, Spies CD. Suppression of interleukin-6 to interleukin-10 ratio in chronic alcoholics: association with postoperative infections. Intensive Care Med. 2002;28:285-92

54. Tonnesen H, Rosenberg J, Nielsen HJ, Rasmussen V, Hauge C, Pedersen IK, Kehlet H. Effect of preoperative abstinence on poor postoperative outcome in alcohol misusers: randomised controlled trial. BMJ. 1999;318:1311-6.

\section{Correspondence:}

Rodrigo Severo de Camargo Pereira

Faculdade de Medicina de Botucatu-UNESP

Departamento de Cirurgia e Ortopedia

Rubião Junior, SN, Anexo Verde

18618-970 Botucatu - SP Brasil

Tel.: (55 14)3813-9227

Fax: (55 14)38157428

rodrigomacarena@yahoo.com.br

Received: October 11, 2011

Review: December 07, 2011

Accepted: January 10, 2012

Conflict of interest: none

Financial source: none

${ }^{1}$ Research performed at Surgical Technique and Experimental Surgery Laboratory, Botucatu Medical School. Sao Paulo State University (UNESP), Brazil. 